\title{
Instagram dan Self Disclosure dalam Perspektif Komunikasi Antarpribadi terhadap Siswa - Siswi SMA Santo Kristoforus II
}

\author{
Jovita Clarissa, H.H. Daniel Tamburian \\ clarisaa,jovitaa@gmail.com,danielt@fikom.untar.ac.id \\ Fakultas Ilmu Komunikasi Universitas Tarumanagara
}

\begin{abstract}
Humans are social beings who need other individuals to group. In interacting with others, individuals will convey information and usually begin with an introduction relates to self disclosure, which is the type of individual communication disclosing information about himself is commonly concealed. Social media is a medium on the Internet that allows users to represent themselves, share, communicate with others and create virtual social ties. This research was intended to examine Instagram and Self Disclosure in an interpersonal communication perspective on the Santo Kristoforus II high school students to find out the activities of students on Instagram social media. Research based on Self-Disclosure theory, communication theory in the Digital Era, social media, and Instagram. Research uses a qualitative approach with case study methods. The results is that the self disclosure conducted by the informant is about daily activities, and the self disclosure is on Instagram involving several Self-Disclosure processes. In the process of Self-Disclosure, informants usually provide personal information such as feelings, thoughts and experiences, and they are also careful enough in uploading information to social media
\end{abstract}

Keywords: interpersonal communication, self disclosure, social media

\begin{abstract}
Abstrak
Manusia disebut makhluk yang memerlukan seseorang untuk saling berhubungan timbal balik. Dalam berinteraksi dengan orang lain, individu akan menyampaikan berbagai informasi dan biasanya diawali dengan perkenalan mengenai dirinya, hal tersebut berkaitan dengan self disclosure, yakni jenis komunikasi individu mengungkapkan informasi tentang dirinya sendiri yang biasa disembunyikan. Media sosial saat ini digunakan penggunanya untuk berkomunikasi, membentuk relasi dengan orang lain secara virtual. Sehingga penelitian ini dimaksudkan untuk meneliti Instagram dan Self Disclosure dalam Perspektif Komunikasi Antarpribadi terhadap Siswa-Siswi SMA Santo Kristoforus II untuk mengetahui aktivitas siswa-siswi di media sosial Instagram. Penelitian berlandaskan teori Self-Disclosure, Teori Komunikasi di Era Digital, Media Sosial, dan Instagram. Penelitian menggunakan pendekatan kualitatif dengan metode studi kasus. Hasil penelitian menunjukkan bahwa pengungkapan diri yang dilakukan oleh informan berisi tentang aktivitas sehari-hari yang dilakukan, dan pengungkapan diri tersebut dilakukan dalam media sosial Instagram yang melibatkan beberapa proses pengungkapan diri. Dalam proses pengungkapan diri, informan biasanya memberikan informasi pribadi seperti perasaan, pikiran dan pengalaman. Dengan banyaknya informasi yang diberikan, tidak menutup kemungkinan mereka juga cukup berhati-hati dalam mengunggah informasi ke media sosial
\end{abstract}

Kata Kunci: komunikasi antarpribadi, media sosial, pengungkapan diri. 


\section{Pendahuluan}

Manusia disebut makhluk sosial yang membutuhkan seseorang untuk berhubungan timbal balik. Berinteraksi dengan orang lain merupakan aktivitas yang tidak pernah lepas dari hidup seseorang. Dalam lingkungan keluarga, individu melakukan interaksi dengan keluarga, dan lingkungan masyarakat yang lebih luas, individu diajak untuk menjalin hubungan dengan makhluk sosial lainnya. Dalam berinteraksi, seseorang akan menyampaikan informasi, dan biasanya diawali dengan perkenalan mengenai dirinya, hal tersebut berkaitan dengan self disclosure, yang berarti jenis komunikasi seseorang mengungkapkan informasi tentang dirinya sendiri yang biasanya disembunyikan. (DeVito, 2010)

Pengungkapan diri (self disclosure) biasanya dilakukan individu kepada orang lain yang sudah dikenal sebelumnya, seperti orang tua dan sahabat. Tidak hanya kepada sesama manusia, namun saat ini pengungkapan diri mulai terjadi dengan adanya media perantara, yaitu media sosial. Sarana ini menjadi wadah bagi seseorang yang ingin berbagi emosi, perasaan, dan aktivitas sehari-hari. Hal ini dinamakan pengungkapan diri dengan perantara media sosial.

Menurut Wood dalam Hasan (2016) Self-Disclosure yaitu pengungkapan diri sendiri yang tidak diketahui oleh orang lain. Seseorang belajar untuk membuka diri ketika individu tersebut memberikan informasi pribadi mengenai diri sendiri, seperti pengalaman, emosi, aktivitas, keseharian. Tindakan ini biasanya mengundang orang yang bersangkutan untuk membuka diri.

Ada 5 aspek dalam self disclosure yaitu ketepatan, motivasi, waktu, keintensifan, dan kedalaman. Ketepatan membahas mengenai apakah seseorang mengungkapkan informasi dirinya sesuai dengan kejadian sebenarnya sesuai dengan norma yang berlaku dalam internet. Motivasi membahas mengenai hal apa yang mendorong seseorang untuk mengungkapkan dirinya kepada orang lain. Dorongan dapat berupa dari dalam dan luar. Dorongan dari dalam diri seseorang sesuai dengan tujuan seseorang untuk melakukan self disclosure. Lamanya waktu seseorang saat bersama orang lain akan meningkatkan kemungkinan terjadinya self disclosure. Saat yang tepat untuk melakukan pengungkapan diri adalah saat individu sudah mengenal seseorang sejak lama. Biasanya karena sudah terbiasa bertemu dengan orang tersebut, akan lebih mudah bagi individu untuk mengungkapkan dirinya. Keintensifan seseorang dalam melakukan pengungkapan diri bergantung kepada siapa seseorang mengungkapkan dirinya, kepada sahabat, orang tua, teman atau orang yang baru dikenal. Kedalaman terbagi atas dua yaitu dangkal dan dalam. Self disclosure yang dangkal terhadap orang yang baru dikenal. Saat bertemu orang baru biasanya akan diceritakan hal-hal umum dalam aspek geografis misalnya nama, daerah asal dan tempat tinggal.

Media sosial saat ini digunakan penggunanya untuk berkomunikasi, membentuk relasi dengan orang lain secara virtual (Nasrullah, 2017). Munculnya media sosial ini tentu memberikan kemudahan dalam melakukan penyebaran informasi mengenai apapun kepada setiap orang. Sebelum adanya media sosial, perkenalan dilakukan dengan bertukar kartu nama, sedangkan saat ini beberapa orang cenderung membuat pertemanan di media sosial. Menurut data www.tempo.com dalam Azeharie (2015) Instagram dikenal sebagai aplikasi yang menjadi trend. Aplikasi ini digunakan pengguna mengambil foto dan membagikan hasil foto ke media sosial. 
Dalam penelitian ini, penulis memilih Instagram karena fitur Instagram lebih cocok untuk dijadikan sebagai obyek penelitian. Fitur yang terdapat pada Instagram yaitu Instagram Stories, siaran langsung (IG-TV), foto dan video. Media sosial dijadikan wadah untuk mereka berbagi cerita mengenai kegiatan sehari-hari, kesukaan hingga keluh kesah. Penelitian ini dilakukan di SMA Santo Kristoforus II terkait dengan bagaimana self disclosure remaja SMA Santo Kristoforus II yang aktif menggunakan sosial media Instagram. Alasan penulis memilih SMA Santo Kristoforus II menjadi bahan penelitian dikarenakan penulis ingin mengetahui aktivitas SMA Santo Kristoforus II dan bagaimana mereka mengungkapkan diri mereka di Instagram. Dengan ini, penulis tertarik untuk meneliti dan membahas topik tersebut menjadi sebuah skripsi dengan judul "Instagram Stories dan Self Disclosure dalam Perspektif Komunikasi Antarpribadi terhadap Siswa-Siswi SMA Santo Kristoforus II". Tujuan dari penelitian ini untuk mengetahui aktivitas siswa-siswi SMA Santo Kristoforus II di media sosial Instagram, serta mengetahui bagaimana siswa-siswi SMA Santo Kristoforus II mengungkapkan diri pribadi mereka di Instagram.

\section{Metode Penelitian}

Dalam menyusun penelitian ini, pendekatan penelitian yang digunakan adalah penelitian kualitatif deskriptif. Penelitian kualitatif deskriptif dipilih untuk menggambarkan aktivitas pengungkapan diri yang menjadi objek dalam penelitian. Penelitian ini menggunakan metode penelitian kualitatif menggunakan pendekatan studi kasus. Menurut Yin (2011) studi kasus adalah strategi cocok bila pokok penelitian berkenaan dengan "Bagaimana" dan "Mengapa", jika peneliti hanya memiliki sedikit kesempatan untuk memantau peristiwa yang terjadi masa kini.

Menurut Arikunto (2016) subjek penelitian adalah orang yang diminta untuk memberikan keterangan tentang suatu fakta atau pendapat, yang dituju untuk diteliti oleh peneliti untuk mengungkap fakta di lapangan. Subyek memiliki kriteria siswasiswi berusia 16-18 tahun, merupakan murid dari SMA Santo Kristoforus II dan menggunakan Instagram. Subjek yang masuk ke dalam kriteria adalah Aurelia Steffany, Agatha Karine, dan Yovanka Annabella. Objek dalam penelitian kualitatif adalah obyek yang alamiah, atau natural setting. Yang dimaksud dengan obyek yang alamiah yaitu objek yang bersifat apa adanya, tidak dimanipulasi oleh peneliti sehingga saat peneliti mulai mengamati obyek, saat berada di obyek dan saat keluar dari obyek tidak ada perubahan (Sugiyono, 2016: 2). Obyek dalam penelitian ini adalah self disclosure melalui fitur Instagram. Fenomena yang penulis ambil adalah pengungkapan diri yang banyak dilakukan oleh siswa-siswi SMA Santo Kristoforus II dalam Instagram.

Metode pengumpulan data disebut langkah awal dalam sebuah penelitian, karena hal yang ingin dicapai adalah memperoleh sebuah data. Jika penelitian dilakukan tanpa menyadari apa saja metodenya, maka peneliti tidak akan mendapatkan data yang sesuai dengan standar yang ditetapkan (Sugiyono, 2010). Metode pengumpulan data yang dilakukan antara lain observasi, wawancara, dokumentasi. Observasi yang dilakukan peneliti adalah observasi non-partisipatif, yaitu peneliti tidak terlibat dalam kegiatan seseorang yang digunakan sebagai sumber data penelitian dan mengamati secara langsung proses pengungkapan diri (self disclosure) siswa-siswi SMA Santo Kristoforus II melalui konten yang diunggah di Instagram Stories. 
Peneliti mewawancarai beberapa informan yang sudah terpilih. Teknik ini dilakukan oleh peneliti dengan alasan peneliti ingin mencari dan mengamati aktivitas pengungkapan diri seorang siswa-siswi secara lebih rinci sehingga pertanyaan yang diberikan kepada informan cukup fleksibel, peneliti juga dapat mengerti lebih rinci mengenai self disclosure informan bergantung kepada jawaban yang diberikan.

Sumber dari dokumentasi ini dapat berasal dari bukti screenshot status atau stories responden dari handphone yang diunggah melalui media sosial mereka. Setiap bentuk pengungkapan diri yang dilakukan siswa-siswi SMA Santo Kristoforus II akan dijadikan bukti sebagai proses pengungkapan diri.

Analisis data merupakan proses mencari serta menyusun data secara sistematis yang diperoleh dari wawancara, dokumentasi, dengan mengatur data ke kategori, dijabarkan, melakukan sintesis, dan menyeleksi hal yang penting untuk dipelajari, dibuat kesimpulan agar mudah dimengerti oleh orang lain (Sugiyono, 2016). Peneliti menggunakan teknik analisis data interaktif dalam penelitian ini. Miles and Huberman dalam (Sugiyono, 2016) mengatakan bahwa kegiatan dalam proses analisis data dilakukan secara terus menerus sehingga data sudah jenuh. Analisis data terbagi menjadi tiga yaitu: Reduksi Data, Penyajian Data dan Penarikan Kesimpulan.

Reduksi data berarti merangkum, menyeleksi hal yang pokok, memfokuskan kepada hal yang penting, mencari tema serta pola (Sugiyono, 2016). Dalam mereduksi data, peneliti akan diiringi oleh tujuan utama dari penelitian kualitatif yaitu temuan. Setiap peneliti yang akan melakukan penelitian harus menentukan perhatiannya jika menemukan segala sesuatu yang asing, belum memiliki pola dan tidak dikenal untuk dilakukan reduksi data. Menurut Sugiyono (2016) dalam penelitian kualitatif, penyajian data dapat dilakukan dalam bentuk teks, hubungan antar kategori, bagan dan sejenisnya. Dengan melakukan penyajian data, maka akan mempermudah peneliti untuk mengerti dan memahami apa yang terjadi, melanjutkan pekerjaan selanjutnya berdasarkan apa yang telah dimengerti. Langkah akhir dalam proses pengumpulan data adalah menarik kesimpulan. Apabila kesimpulan yang dikemukakan sejak awal telah didukung bukti yang kuat dan konsisten saat proses pengumpulan data, maka kesimpulan yang didapatkan merupakan kesimpulan yang kredibel.

Untuk membuktikan keabsahan data dari penelitian ini, perlu digunakan teknik untuk memeriksa keabsahan sebuah data. Dalam penelitian ini penulis menggunakan teknik triangulasi dengan metode sumber data, penulis melakukan perekaman saat proses wawancara sebagai pembanding dan pengecek derajat kepercayaan suatu data dalam waktu yang berbeda. Dengan membandingkan hasil tersebut, penulis melakukan wawancara dalam waktu dan lokasi yang tidak sama.

\section{Hasil Temuan dan Diskusi}

\section{Self Disclosure dan Siswa-Siswi SMA Santo Kristoforus II}

Dalam proses pengungkapan diri, individu dapat mempresentasikan dirinya sebagai orang bijak atau orang bodoh tergantung pada cara seseorang mengungkapkan perasaan, tingkah laku dan kebiasaan. Individu belajar untuk membuka diri ketika individu tersebut memberikan informasi pribadi mengenai diri sendiri, seperti harapan, ketakutan, perasaan, pikiran dan pengalaman. Tindakan membuka diri cenderung mengundang orang yang bersangkutan untuk membuka diri juga. Hal ini dikarenakan adanya sikap saling percaya sehingga individu yang mengetahui informasi pribadi orang lain akan membuka diri dengan memberikan informasi mengenai dirinya kepada orang tersebut. 
Aspek dalam pengungkapan diri ada 5 yaitu ketepatan, motivasi, waktu, keintensifan dan kedalaman Ketepatan membahas mengenai apakah seseorang mengungkapkan informasi dirinya sesuai dengan kejadian sebenarnya sesuai dengan norma yang berlaku dalam internet Pengungkapan diri yang benar berarti seseorang mengerti serta bertanggung jawab atas segala hal yang akan diperoleh ketika seseorang mengungkapkan diri di internet dengan cara yang tidak sesuai norma yang berlaku. Pengungkapan diri yang positif akan mendapatkan timbal balik yang positif juga dari para pendengar. Sedangkan, pengungkapan diri yang kurang tepat memiliki arti seseorang mengungkapkan informasi mengungkapkan informasi mengenai dirinya tidak sesuai dengan yang sebenarnya terjadi.

Motivasi merupakan aspek dari self disclosure yang mendorong seseorang untuk mengungkapkan dirinya. Dorongan dapat berupa dari dalam dan luar. Dorongan dari dalam diri seseorang memiliki ikatan erat dengan hal yang ingin dicapai seseorang untuk melakukan self disclosure. Lamanya waktu seseorang saat bersama dengan orang lain cenderung akan meningkatkan kemungkinan terjadinya self disclosure. Saat yang tepat untuk melakukan pengungkapan diri adalah saat individu sudah mengenal seseorang sejak lama. Biasanya karena sudah terbiasa bertemu dengan orang tersebut, akan lebih mudah bagi individu untuk mengungkapkan dirinya. Jika individu dalam keadaan baik dan senang, ia tidak akan tertutup dengan orang lain atau beberapa orang yang dikenalnya. Sedangkan saat individu merasa sedang dalam keadaan yang seperti sakit atau sedih, akan lebih sulit untuk terbuka.

Keintensifan seseorang saat melakukan self disclosure bergantung kepada siapa individu mengungkapkan dirinya, kepada orang tua, teman biasa atau orang yang baru pertama kali bertemu. Semakin dekat individu dengan orang yang disekitarnya, maka pengungkapan diri akan dilakukan secara terus menerus dan dengan sungguhsungguh. Kedalaman terdiri atas dua bagian yaitu self disclosure yang dangkal dan dalam. Self disclosure yang dangkal terjadi pada orang yang baru pertama kali kenal. Kepada orang yang baru dikenal akan diceritakan hal-hal umum dalam aspek geografis misalnya identitas pribadi. Sedangkan self disclosure yang dalam biasanya dilakukan kepada orang yang memiliki hubungan dekat. Kedalaman yang tepat terjadi bila seseorang dapat membedakan topik yang sesuai untuk didiskusikan. Topik mengenai kesehatan, karir, pendidikan, keinginan, dan hal umum lainnya akan dibicarakan kepada orang yang baru dikenal, sedangkan topik yang menyangkut masalah pribadi hanya dibicarakan dengan orang-orang terdekat.

DeVito dalam Indriyani (2018) mengemukakan beberapa faktor yang memengaruhi pengungkapan diri yaitu besarnya kelompok, perasaan menyukai, efek diadik, kompetensi, kepribadian, topik, dan jenis kelamin. Jika pengungkapan diri dilakukan kepada lebih dari satu pendengar, maka orang tersebut akan kesulitan dalam memahami tanggapan yang diungkapkan pendengar karena setiap pendengar memiliki pendapat yang berbeda-beda. Jika mengungkapkan diri kepada satu atau dua pendengar, individu tersebut akan lebih berkonsentrasi terhadap pendapat yang diberikan dan lebih mengerti apa maksud dari orang yang memberikan pendapat.

Besarnya kelompok menjadi salah satu faktor yang mempengaruhi SelfDisclosure, seperti informan yang juga merasa ketika mengungkapkan diri kepada kelompok besar seperti Instagram, informan akan merasa kesulitan dalam memahami tanggapan yang diungkapkan karena setiap pendengar memiliki pendapat yang berbeda. Sedangkan ketika informan mengungkapkan diri kepada satu atau dua pendengar, informan akan lebih berkonsentrasi terhadap pendapat yang diberikan dan lebih mengerti maksud dari pendengar. 
Individu yang kompeten dinilai lebih banyak melakukan pengungkapan diri daripada orang yang tidak kompeten. Hal ini dikarenakan seseorang yang lebih kompeten kemungkinan memiliki lebih banyak hal positif untuk dibagikan kepada orang lain untuk diungkapkan. Dalam faktor kepribadian, seseorang yang pandai bergaul dan extrovert (seseorang yang menyukai lingkungan yang interaktif, antusias dalam hal baru dan senang bergaul) mengungkapkan dirinya lebih banyak daripada individu yang kurang pandai bergaul dan introvert. Kedua informan memiliki kepribadian yang pandai bergaul dan menyukai lingkungan yang interaktif. Sedangkan informan lainnya merasa kurang berani berbicara di depan umum, sehingga ia tidak terlalu mengungkapkan dirinya kepada orang secara terus terang. Tetapi, informan mengungkapkan dirinya dengan mengunggah hal yang ia sukai dan tekuni sehingga publik dapat mencari tahu keseharian dan kesukaannya melalui gambar yang informan unggah di akun Instagram.

Kemajuan perkembangan komunikasi ditandai dengan berbagai perubahan di bidang media massa yang ditandai dengan hadirnya media digital yang telah membawa pengaruh terhadap pola-pola komunikasi masyarakat. Semua pesan yang diproduksi akan semakin cepat menjangkau sasaran yang mampu menembus dimensi waktu dan batas geografis. Majunya perkembangan komunikasi yang dibantu dengan internet membuat informan menjadi lebih terbuka kepada orang lain, seperti memberitahu kejadian yang sedang informan alami, apa yang informan rasakan, dan informan ingin dikenal sebagai seorang yang memiliki kepribadian yang baik dan positif. Dengan kemajuan komunikasi terutama setelah munculnya internet manusia akan dapat berkomunikasi antarpribadi secara keseluruhan.

Dalam konteks pengungkapan diri yang dilakukan ketiga informan akan dikaitkan dengan teori Jendela Johari. Dalam diri terbuka berarti individu mengenal dirinya dengan baik, begitu pula dengan orang lain. Jika dilihat dari pengungkapan diri ketiga informan, yang terjadi adalah individu tetap berani untuk menyebarkan informasi dan membagikan curahan hatinya melalui Instagram Story yang dapat diketahui oleh publik secara luas. Dengan melakukan pengungkapan diri, tentu informan mengerti bahwa ia sedang mengungkapkan dirinya dan paham mengenai pesan yang disampaikannya. Pesan yang disampaikan bertujuan agar pembaca mengerti masalah yang sedang dialami oleh individu.

Pada daerah diri buta, diri kita dapat diketahui oleh orang lain sedangkan diri kita sendiri tidak mengerti. Hal ini erat kaitannya dengan over disclosure, yaitu sikap pengungkapan diri yang terlalu banyak sehingga hal yang seharusnya rahasia, justru diungkapkan melalui media sosial. Dalam penelitian yang dilakukan dengan ketiga informan, over disclosure tidak terlalu terikat pada diri mereka. Informan 1 dan 2 menyatakan bahwa mengungkapkan diri secukupnya saja. Masalah pribadi akan tetap dirahasiakan dan tidak disebarkan melalui media sosial. Informan 3 juga tidak berlebihan dalam melakukan pengungkapan diri, karena takut membuat orang lain tidak nyaman. Dalam diri tersembunyi mengenai informasi diri kita, hanya kita yang mengerti dan orang lain tidak. Dalam konteks penelitian dengan ketiga informan, mereka memilih untuk tetap mengungkapkan dirinya namun tetap berhati-hati dan menyaring ketika menceritakan masalah yang sedang dialami. Informan 1 hanya menuliskan suatu hal yang mewakili dirinya namun tidak menjelaskan inti permasalahan, sehingga orang tidak langsung menilai seperti apa dirinya. Informan juga merasa takut publik merasa salah paham dengan apa yang sebenarnya terjadi. 
Diri yang tidak dikenal siapapun berisi informasi mengenai pribadi yang tidak diketahui oleh kita sendiri dan orang lain. Untuk dapat mengetahui daerah ini dapat dilakukan dengan interaksi secara intens. Hal tersebut tidak berlaku dalam pengungkapan diri melalui Instagram Story, dikarenakan merupakan ruang publik yang dapat diakses oleh siapa saja.

\section{Simpulan}

Proses pengungkapan diri yang dilakukan oleh informan yang merupakan siswa-siswi SMA Santo Kristoforus II berisi tentang aktivitas sehari-hari yang dilakukan, dan pengungkapan diri tersebut dilakukan dalam media sosial Instagram yang melibatkan beberapa proses pengungkapan diri. Ketiga narasumber memulai proses pengungkapan diri dengan membuat akun media sosial Instagram karena narasumber menganggap Instagram adalah wadah yang tepat untuk mengungkapkan diri mereka. Dalam pengungkapan diri yang dilakukan informan, biasanya informasi yang diberikan seperti pengalaman hidup, emosi, cita-cita, hubungan pertemanannya, dan lain-lain. Informan juga belajar untuk membuka diri dengan mulai mengungkapkan informasi pribadi seperti harapan, ketakutan, perasaan, pikiran dan pengalaman. Dengan banyaknya informasi pribadi yang diberikan informan, tidak menutup kemungkinan mereka juga cukup berhati-hati dalam mengunggah informasi karena menurut mereka foto-foto yang dimasukkan ke media sosial akan sangat mudah diambil alih oleh orang lain, dan kemungkinan terburuk akan disalahgunakan oleh orang yang tidak bertanggung jawab.

\section{Ucapan Terima Kasih}

Peneliti mengucapkan terima kasih kepada keluarga yang senantiasa membantu peneliti selama proses penulisan skripsi. Serta kepada para siswi SMA Santo Kristoforus II, Agatha Karine, Aurelia Steffany dan Yovanka Annabella yang telah bersedia menjadi informan.

\section{Daftar Pustaka}

Arikunto, Suharsimi. (2006). Prosedur Penelitian: Suatu Pendekatan Praktik, Edisi Revisi VI, Jakarta : PT Rineka Cipta.

Azeharie, Suzy., \& Sari, Wulan Purnama. (2015). Penyingkapan Diri Ibas Yudhoyono Dalam Instagram dan Reaksi Ani Yudhoyono Terhadap Postingan Instagram. Ibas. Jurnal Komunikasi, 7, 1, 108-117. Terarsip di https://journal.untar.ac.id/index.php/komunikasi/article/view/11/32.

Devito, Joseph. A. (2010). The Interpersonal Communication Book USA: Pearson International Edition.

Hasan, Muhammad Rifky. (2016). Motif Diversi dan Self - Disclosure pada Mahasiswa Pengguna Instagram. Jurnal Universitas Islam Indonesia. 3 September 2019. Terarsip di: https://dspace.uii.ac.id/handle/123456789/10426.

Indriyani, Ririn. (2018). Pengungkapan Diri Siswa di Media Sosial Instagram (Studi Deskriptif Terhadap Siswa Kelas XI SMA Negeri 2 Kuningan. Skripsi Thesis. 3 September 2019. Terarsip di: https://repository.usd.ac.id/31259/. 
Moleong, Lexy. (2017). Metodologi Penelitian Kualitatif Edisi Revisi. PT. Remaja Rosdakarya Offset.

Nasrullah, Rulli. (2016). Media Sosial Perspektif Komunikasi, Budaya dan Sosioteknologi. Bandung. Simbiosa Rekatama Media.

Sagiyanto, Asriyani. (2018). Self Disclosure melalui Media Sosial Instagram (Studi Kasus pada Anggota Galeri Quote). Journal of Communication. April 2018. Terarsip di http://jurnal.umt.ac.id/index.php/nyimak/article/viewFile/687/499 Sugiyono. (2016). Memahami Penelitian Kualitatif. Bandung. Penerbit CV. Alfabeta. Yin, Robert K. (2011). Studi Kasus: Desain dan Metode. Jakarta. Rajagrafindo Persada. 